$18-08-2010$

\title{
Rationalism and Public Policy: Mode of Analysis or Symbolic Politics?*
}

\author{
Denis Saint-Martin \\ Département de science politique \\ Université de Montréal \\ Denis.Saint-Martin@umontreal.ca
}

\author{
Christine Rothmayr Allison \\ Département de science politique \\ Université de Montréal \\ Christine.Rothmayr.Allison@umontreal.ca
}

\begin{abstract}
:
This article takes up the distinction between incremental analysis and incremental politics as elaborated by Lindblom in his 1979 article. We argue that while rationalism as a mode of analysis has lost much of its prominence, rationalism as symbolic politics is still very much alive and might even be more present today than it was back when Lindblom wrote his famous 1959 article. The recent shift to new modes of governance whereby elected officials are increasingly delegating decision-making powers to independent bureaucracies - what Majone calls the "regulatory state" or what the British describe as "agencification" or quangoisation" - has created an important legitimacy deficit for those non-majoritarian institutions that exercise political authority without enjoying any direct link to the electoral process. In such a context - and in addition to growing public distrust towards partisan politics - rationalist politics is likely to become more rampant as independent bureaucracies lack the legitimacy to publicly recognize the fundamentally incrementalist - and thus values-laden - nature of their decision-making processes. To develop these ideas, the article looks at the case of "supreme audit institutions". We argue that rationalist politics is a mean for SAIs to legitimize their shift from classical financial auditing to performance auditing. In comparison to other independent bureaucracies, they are particularly prone to rationalist politics not just because of their institutional independence, but also because of the tradition of financial auditing and the rise of new public management.
\end{abstract}

Keywords: incremental politics, rational politics, performance auditing, evaluation, supreme audit institutions, independent bureaucracies

* I would like to thank Leslie Pal for his helpful comments on an earlier version of this article. 
In 1959, the synoptic model was dominant in decision analysis and represented the main adversary against which Lindblom developed his incisive critique of theoretical approaches that depicted policy-making as an exercise in means/ends rationality based on the analysis of comprehensive information. Since the publication of Lindblom's seminal article, various theoretical developments have successfully contested rationalism's former dominant position ${ }^{1}$. We think not just of the argumentative turn in policy analysis, but also of the renewed interest in bounded rationality within the policy agenda literature or the concept of path-dependency in historical institutionalism. Today, what we are left with is not so much rationalism as an empirically credible theory or mode of analysis, but rationalism as a form of symbolic politics that various bureaucratic entities use to project the "illusion" of rational comprehensive decision-making as a strategy to legitimize the exercise of political power. This is the key proposition we explore this paper.

In the same way that Lindblom recognized in his "Still Muddling, Not Yet Through" 1979 article the need to differentiate between incremental analysis and incremental politics, this article uses a similar distinction and suggests that although the image of an omniscient decision-maker with no cognitive limit able to process all the relevant information has probably disappeared from most public policy textbooks, rationalist politics is still very much alive and might even be more present today than it was back when Lindblom wrote his famous article. By rationalist politics we mean, that public officials, especially those working in independent bureaucracies, mobilize the rational mode of analysis in order to

\footnotetext{
${ }^{1}$ In documenting the division between the "synoptic and anti-synoptic traditions" in social science, Garson writes that, following the publication of Lindblom's article in 1959, "the anti-synoptic view quickly became dominant in political science generally, [but] the synoptic tradition proved far more viable in the fields of public administration and public policy" (1981, p. 538).
} 
publicly justify and legitimize their action. The recent shift to new modes of governance whereby elected officials are increasingly delegating decision-making powers to independent bureaucracies - what Majone calls the "regulatory state" or what the British describe as "agencification" or "quangoisation" - has created an important legitimacy deficit for those non-majoritarian institutions that exercise political authority without enjoying any direct link to the electoral process (Majone, 1999). In such a context - and in addition to growing public distrust towards partisan politics - rationalist politics is likely to become more rampant as independent bureaucracies often lack the legitimacy to openly acknowledge the fundamentally incrementalist and thus political nature of their decision-making processes.

Our argument is not that rationalist politics is a form of conspiracy whereby unelected bureaucrats secretly seek to usurp the power of democratically elected officials. It is also different from what Yates calls "silent politics", which looks at how rational but impossible management schemes allow bureaucrats to negotiate and settle value-laden issues, without choices being raised to the attention of politicians or the public (Yates, 1982). Rather, our goal is to highlight the symbolic role of the synoptic-rational model in politics today: how it constitutes a tool for (some) independent bureaucracies to demonstrate their conformity to rational rules, enhance the credibility of their decisions and thus foster the legitimacy of their actions (Boswell, 2009).

Delegating powers to unelected bodies operating independently from government always raises issues of legitimacy and accountability (Thatcher, 2002). As often argued in the 
literature, the legitimacy of independent agencies depends on their expertise and the robustness of the technical or scientific rationale underlying their decision processes (Schrefler, 2010). By being seen to draw on the rational/synoptic model, an organization can enhance its legitimacy and authority (Boswell, 2008). To develop this idea, and to provide some suggestive illustrations in its support, the paper draws on the work of DiMaggio and Powell (1983) on institutional isomorphism as a source of legitimacy and relies on empirical material derived from comparative studies looking at the evolution of "supreme audit institutions" (SAIs). SAIs are arguably among the most independent bureaucratic institutions currently existing in modern polities (Pollitt, and Summa, 1999). With the "audit explosion" and the rise of the new public management (Power, 2003), the role of SAIs has been significantly broadened to encompass wider issues of efficiency, effectiveness and value for money (Glynn, 1985). This should make them an ideal site to observe how rationalist politics operates, as their independence is based on a form of technocratic legitimacy that makes SAIs more likely to project a view of the policy process that is closer to the synoptic than to the more political incrementalist model.

\section{The Normative Power of the Synoptic Model}

For all its faults, the synoptic model and the belief that advances in knowledge and technology can help solve social problems still remains an ideal in complex modern societies (Ferris, 2010). It is something to strive for, as "the rational-comprehensive model has at least the advantage of stimulating administrators to get a little outside of their regular routine" (Dror, 1964, p.155). The synoptic approach has a powerful normative appeal and as much of the research shows, norms take time to change (Gabler, 
2010). The notion of science as "in service to democracy" is a recurrent theme in the policy literature, as in everyday political discourse (DeLeon, 1997). What makes the synoptic model a particularly attractive tool for independent bureaucracies lacking democratic legitimacy is its appearance of neutrality, being founded as it is on the positivistic fact-value dichotomy (Hawkesworth, 1988), itself intimately linked to the politics-administration dichotomy in public administration (Rosenbloom, 2008). Together, these dichotomies assume a firm distinction between the empirical and normative dimensions of policy issues. Normative questions, since they are viewed as resting on subjective value judgements, are considered inappropriate for bureaucrats to deal with. As a result, their work is usually portrayed as a purely neutral activity, nonnormative and apolitical. This makes it possible to "keep the lid" on what Behn calls "the dirty little secret of public administration: civil servants do make policy" (2001, p.64). They do make values judgments but "typically, they disclaim that they are doing any such thing. They insist that they are merely filling in the administrative details of overall policies established by their political superiors" (Behn, 2001, p.64).

Of course, Lindblom discarded the fact-value dichotomy and argued instead that the choice of ends and means were closely intertwined in the decision process (1959, pp.8183). His seminal 1959 article and frontal attack on rationalism opened the doors for the subsequent development of more critical approaches, including post-positivism and the argumentative turn in policy analysis (Stone, 2002). Contemporary policy theory increasingly assumes a pluralist political framework and what Fischer calls "postempiricist" epistemologies (2003). "As rationalist and synoptic models of policy making 
gave way to models based on incrementalism, negotiation and bargaining" writes Mary Henkel, "so the ideal of objective, value-free social science faded" (1991, p.122). More and more policy theorists seek to move beyond an 'objectivist' conception of reality and recognize that 'facts' are always theory-laden and thus subject to interpretations and contestations. This research suggests that understandings of the social world are framed through the discourses of the actors themselves, rather than fixed in nature (Fischer, 2009). Nowadays, policy analysts are more in the business of providing persuasive arguments rather than conclusive judgements (Majone, 1989).

But while incrementalism may well have had a major impact on what policy scholars in academia do, its effect on politics and on the "real world" of public policy seems to have been more limited. This would not come as a surprise to Lindblom himself, since he consistently rejected the idea that knowledge, policy analysis or social science had much impact on what governments do (Lindblom, 1992).

Incrementalism and the post-positivist approaches that followed it have real political implications, and these implications prevent them from fitting easily into policy-making structures. Much of professional policy analysis takes place in government institutions, and that analysis, according to Pal, "presents itself as neutral and non-partisan". As he wrote, a "key phenomenon of modern government is the way in which policy discourse is conducted as though it were neutral and objective. This reflects a belief in the positivist tradition of policy analysis: that pure, objective policy truths do exist" (1992, p.66). 
Incrementalism is subversive for public administration because it puts into question the notion that elected officials are "on top" and bureaucrats and experts "on tap". It challenges traditional conceptions that view accountability as a tidy, linear and hierarchical process. People elect their representatives; these individuals then decide which values and policy goals to pursue and they subsequently turn to the administrative apparatus to find and adopt the most efficient mean to implement policy. If citizens do not like their government's policies they can vote their elected officials out of office. This distinction between politics and administration permits the construction of a simple, appealing, hierarchical model of accountability. And despite its flaws, that model has one, big advantage: political legitimacy.

So, while incrementalism may make good sense intellectually, it is politically problematic for ministers and bureaucrats in government. If ministers publicly acknowledge that bureaucrats do make policy decisions, they risk undermining their authority and leadership as the hierarchical head of their department. And if bureaucrats openly admit that they make political values judgements, they risk eroding the permanence of the civil service, which is linked to its apolitical nature. These forces not only discourage the use of incremental and post-positivist approaches, but also help to explain the persistence of the synoptic model and its positivist methodologies, despite the fact that their intellectual foundations were undermined a long time ago. Moreover, "the aura of science and objectivity that surrounds positivist policy analysis adds to the image of the policy analyst as an apolitical technocrat" (Amy, 1984, p.211). This technocratic image is much of what justifies the role of bureaucrats in the policy-making system. It 
underlies what McSwite calls the "Man of Reason model of the public administrator's role" (1997). Thus, while the notion that decision-making is a purely rational activity is clearly a fiction, it is a politically useful fiction to cultivate.

\section{Bureaucratic Independence and Democratic Legitimacy}

Independent bureaucratic institutions always face a problem of legitimacy in democratic systems of representative government (Vibert, 2007). But not all such institutions are equally independent (Carpenter, 2001). In the most general terms, independence refers to a form of separation that ensures other interests or identities will not affect the actions of a specific agent (Clarke, 2005, p.5). Bureaucratic independence is not a static variable. It is not simply the result of institutional design; that is, an effect whose cause is to be found in the decision of rational political principals determining in advance how much independence and authority they are willing to confer upon an organization that they are in the process of designing. Bureaucratic independence evolves over time and largely depends on an organization's reputation for efficiency and expertise and its ability to be seen as providing a unique type of services (Carpenter, 2010).

In the European Union, where much of the recent work on the politics of delegation and bureaucratic autonomy has taken place, the focus so far has been on independent regulatory agencies (IRAs). These bodies are said to fulfill regulatory goals in the public interest (such as rights protection, enforcement of competition rules, or consumer protection) better than central government institutions because they are isolated from the direct scrutiny of voters and changes in government (Gilardi, 2008). But IRAs also play 
an integrative function as nodal points of wider regulatory networks that include national authorities, scientific communities, private enterprises and civil society organisations (Dehousse, 1997). It has been argued in the literature that the systematic inclusion of public and private stakeholders from multiple levels of government in formal and informal transnational networks facilitates the exchange of knowledge and the dynamic forging of consensus (Eberlein \& Grande, 2005). In this sense, IRAs do not really stand "above politics". Their integrative function is indicative of the incremental and negotiated nature of their decision processes. Their role in finding a point of equilibrium among various stakeholders in society suggests that their independence does not involve standing above the "social fray". On the contrary, they are an intrinsic part of that "fray". Because they maintain organized links with civil society, IRAs can invoke norms related to representation to reduce their lack of democratic legitimacy (Borras, Koutakalis \& Wendler, 2007). They have, in EU parlance, some form of "input legitimacy". In this respect, their status is somewhat similar to independent advisory bodies such as Status of Women Canada or the National Seniors Council. These bodies operate at arm's length from government and generally act as policy advocates, representing the voice of a particular sector of society in the governmental process (Malloy, 2003; Pal, 1993). Because they act as "lobbies from within", these organizations cannot act as if they were purely "neutral" - as if they were not representing a particular societal interest. Their very existence is an admission that public policy-making in democratic societies is a process of political bargaining and "partisan mutual adjustment" among competing groups. Whenever they publicly defend a policy position, they are usually not invoking some technical or

${ }^{2}$ Conventionally, input-legitimacy is understood as the degree of inclusiveness and accountability of internal decision-making, while output-legitimacy is measured by the overall effectiveness of the system (Scharpf, 1997). 
scientific principle or the allegedly neutral value of efficiency. They advocate policies on the basis of the more political principles of equality and fairness. And it is precisely because they are perceived as partisan advocates that they are often the targets of political attacks by governments or parties that do not share their ideological stances.

Other independent bureaucracies, however, are more like recluse monks or hermits living insulated from society and politics. They are, in the words of Bowles and White writing about central banks, "the modern embodiment of the Platonic guardians, deemed to be above and beyond the normal political pressures and requirements of democratic societies" (1994, p. 236). This is particularly the case of "supreme audit institutions" (SAIs), the bodies that audit the accounts and expenditures of governments. These institutions are said to be "supreme" - like supreme courts - to underline their position as the highest authority in the audit of government accounts and the extent of their independence (Bowerman, Humphrey \& Owen, 2003). Clarke suggests that SAIs have a form of "knowledge-based independence" where action involves the exercise of specialized knowledge disciplined by codes of conduct and where expertise is understood to be applied in a disinterested fashion (2005, p. 45).

SAIs are national agencies responsible for auditing government revenue and spending. Their legal mandates, reporting relationships, and effectiveness vary, reflecting different governance systems and government policies. But their primary purpose is to oversee the management of public funds and the quality and credibility of governments' reported financial data. Countries in North America and Europe use one of two auditing systems: 
Napoleonic and Westminster. In the Napoleonic system the supreme audit institution also called the cour des comptes - has both judicial and administrative authority and is independent of the legislative and executive branches. The institution is an integral part of the judiciary, rendering judgments on government compliance with laws and regulations as well as ensuring that public funds are well spent. The cour des comptes audits every government body, including ministries, departments, and agencies; commercial and industrial entities under the purview of ministries; and social security bodies. In the Westminster system (used in most Commonwealth countries), the office of the auditor general is an independent body that reports to parliament. Made up of professional auditors and technical experts, the office submits periodic reports on the financial statements and operations of government entities - but with less emphasis on legal compliance than in the Napoleonic system (Pollitt \& Summa, 1999).

SAIs have traditionally performed two types of audit: financial and compliance audits. In financial auditing the auditor assesses the accuracy and fairness of an organization's financial statements. In compliance auditing the auditor checks whether government revenue and spending have been authorized and used for approved purposes. Transactions are reviewed to determine if government departments and agencies have conformed to all pertinent laws and regulations. This process includes checking the spending authority in the annual budget and any relevant legislation. But since at least the late 1970s, performance audit (or value-for-money audit) has taken state audit institutions far beyond their traditional concerns with financial probity and regularity. 
In this article, the focus is on SAIs in the Westminster camp for two reasons. First, because within SAIs the move toward performance audit and questions of program efficiency and effectiveness has been much greater in the countries that are part of this category than in the Napoleonic model. As Pollitt and Summa found, "the language of managerialism - the discourse of justification by measured productivity and/or effectiveness - has penetrated some SAIs less than others" (1997, p. 332). These differences, they argue, are related to the different constitutional positions SAIs occupy in the political system (i.e. independent tribunals vs agents of parliament). Secondly, and more importantly for our argument, in branching into VFM audit, SAIs moved into the more subjective and more controversial territory of public policy analysis. In doing so, they took the risk of being seen as crossing the line between politics and administration (Humphrey, 2001). And as they ran the risk of becoming more embroiled in political territories, SAIs sought to more strongly "reassert their independence, neutrality, scientificity and pragmatism" (Humphrey, 2002, p. 56). It is precisely at this point that rationalist politics intervenes, for the synoptic model provided SAIs involved in performance auditing a mean of legitimizing their new found authority and demonstrating the credibility of their decision processes. It provided a way for SAIs to deploy what Humphrey calls in the British context "a scientific approach to politics" (2002). In Canada, S. L. Sutherland described the model of VFM audit institutionalised in the Office of the Auditor General in the late 1970s as being "characterised by an exaggerated faith in rationality...In this audit model there is a strong faith in the capacity and legitimacy of pure reason in administrative realms to sharply limit traditional political processes for making choices" (1986, p.141). 


\section{Performance Audit, Positivism and Evaluation}

With the development of performance audit, the overall balance of the work of SAIs shifted towards a more evaluative stance (Barzelay, 1997). Performance audit can range from examinations of economy and efficiency of the management of government programs through to determinations of whether goals have been achieved (effectiveness). Just as the purposes of audit have become more diverse, the audit entity, which is to say the organizational or logical parameters within which the scrutiny takes place, has also changed. For the broad-scope VFM studies, it has been shifted away from narrow, concrete audit entities such as budget categories and parliamentary votes, to much broader entities, often whole government programs and departments (Levy, 1996).

These shifts toward performance audits has spurred debate about the differences and similarities between performance audit and program evaluation in terms of methodology, aim and scope, institutional setting, professional culture, contribution to improving governmental performance among other aspects (Chelimsky, 1985; Politt \& Summa 1996; Wisler 1996; Leeuw 1996). Despite similarities, evaluation is a much less certain activity or 'science' than financial audit. As a social science discipline it is methodologically and epistemologically more divers and self-reflexive. Even evaluators working within a positivist paradigm, with experimental and quasi-experimental designs, since long acknowledge that the political context is an essential feature of program evaluation and can not be evacuated or disassociated from evaluation practice (Weiss, 1998; Rossi, Lipsey \& Freeman 2004). In extending their activities to performance audit, SAIs employed a wider range of analytical tools and moved into less solid and more 
political territories. And with this move, the authority of SAIs began to be questioned (Power, 1997). As David Good underlined, “The performance audit, while appearing to ask simple, technical, and seemingly objective questions, actually focuses on the most political and subjective of all questions - How well is government doing?" (2007, p. 218).

While the development of performance auditing in the 1970s and 1980s brought auditing closer to evaluation, at the same time evaluation research and theorists began to raise more and more questions about the nature of social science and the authority of the knowledge derived from it (Nagel, 2001; Pawson \& Tilly, 1997). The initial hopes that the results of scientific, experimental evaluation of programs would simply translate into better policy choices were rapidly disappointed. Instead, evaluators turned to more pragmatic approaches, taking into account the political and institutional realities of programs and turning to new forms of collaborating with stakeholders, through participatory approaches for example, but also through adapting research designs and methods to the messy reality of politics. Others went even further, and entirely rejected positivist notions underpinning much of evaluation practice (Guba \& Lincoln 1989). Hence, as ideas about the applicability, authority, and scientific robustness of evaluations became more circumscribed, new approaches to evaluation increasingly insisted on the fact that evaluation practice is shaped by values (Majone, 1989) and proposed alternative ways for "judging" policies through collaboration, deliberation or even empowerment, hence conceiving alternative roles for evaluators, than being the neutral, independent assessor of facts. 
But this was not how professional auditors and accountants working in SAIs saw their role in performance auditing. As Pollitt and Summa argued, "Performance auditors, notwithstanding their excursions beyond the comfortable world of verification, still wish to present their material as definitive, factual and value-neutral" (1996, p.47). The way SAIs institutionalized performance audit contradicted most post-positivist critiques of policy analysis. They assumed that audits would be summative, delivering authoritative judgements, based as far as possible on performance indicators or quantitative measures of input-output relationships and outcomes and set against predefined targets and standards. The epistemological stance was unequivocally positivist. It assumed that social phenomena could be divorced from their context and that objective knowledge about them could be achieved through empirical observation and quantitatively expressed; that facts were distinct from values and means from ends; that concepts and methods of 'good management' were applicable to the pursuit of any values (Henkel, 1991a).

When politicians began to give SAIs the mandate to conduct VFM audit in the early 1980s, there was no well-developed body of knowledge and techniques for performing such audits, either in government or in the large private accounting firms (McSweeney, 1988, p.30). SAIs approached the development of performance audit from a financial accounting point of view, relying on quantitative methods and on the objectivity and neutrality accorded to numbers (Porter, 1995). As Miller noted, "The single figure provided by the calculative practices of accounting appears to be set apart from political interests and disputes, above the world of intrigue, and beyond debate" (2001, p.382). 
Writing about the creation of the Audit Commission in Britain in the early 1980s, Michael Power argued that "the accountancy base of the Audit Commission undoubtedly gives it a legitimacy that other evaluation bodies lack" (1997, p.116). According to Henkel, this "played a significant part in the acquisition of authority on the part of the Audit Commission" (1991a, p. 224).

\section{The Legitimizing Function of the Synoptic Model}

The large gap between the synoptic model and the complex and often chaotic reality of public policy means that most government services and programs, when submitted to VFM audit, almost never meet the expectations of SAIs (Pollitt, 2003). A cursory glance at the observations and recommendations found in the performance audit reports published by SAIs indicates that the list of problems identified is almost always related to key synoptic assumptions, such as insufficient information, ambiguous goals, lack of coordination, absence of measurable indicators, poor strategic planning and inappropriate management control systems. In other words, the incrementalist nature of how government operates empirically, systematically fails to conform to the theoretical expectations of the synoptic model. The synoptic model suggests that there is a "one best way" but that politicians and bureaucrats are either unable, or worse, unwilling to follow it. This is why SAIs conducting VFM audit are sometimes accused of "negativity" (Corner \& Drewry, 2005, p.76). By consistently criticizing government for failing to meet the expectations of the rational model, they put politicians and bureaucrats into a defensive mode that can stifle creativity, risk-taking and initiative (Roberts, 1996). Could SAIs avoid this outcome by auditing government policies not through the lenses of the 
synoptic but of the incremental model? Could they audit programs and services using post-positivist theories and methods?

That is not likely. In this final section, we suggest that SAIs do not mobilize the synoptic model because of its empirical robustness, but because of its symbolic properties in providing legitimacy for their expanded role in policy evaluation. Scholars have long wondered why certain institutional forms, or policy models and theories - even when their problem-solving capacities are in doubt - are nevertheless the object of mimetic practices by governments and found in many countries and jurisdictions across the globe (Meyer \& Scott, 1983). This is the case, for instance, of central bank independence. While central bank independence has achieved an almost taken for granted quality in political life, the causal links between this particular organisational form and superior economic outcomes is said to be based on "shaky" empirical foundations (McNamara, 2002, p. 59). Sociologists suggest that organizations adopt certain practices and methods not because they are always the most functionally efficient solution to a given problem, but because of their legitimising and symbolic properties (Radaelli, 2000). In these approaches, the choice of theories and organisational models are linked to social processes that legitimate certain types of choices as superior to others. In an influential article, DiMaggio and Powell (1983) argued that organizations within a field often face "normative pressures" to enhance their legitimacy. Such pressures describe the effect of professional standards and the influence of professional communities on organizational characteristics. They capture the ways in which organizations are expected to conform to standards of professionalism and to adopt systems and techniques considered to be 
legitimate by relevant professional groupings. These norms are conveyed through education and training and professional networks.

In the SAIs field, the sources of social interactions and linkages between actors are numerous, found in the accounting bodies at the national level and in various international organizations such as the International Organisation of Supreme Audit Institutions (INTOSAI), the European Organisation of Supreme Audit Institutions (EUROSAI) and the International Center for Performance Auditing. The development of such "epistemic communities" facilitates the forging of expert consensus (Haas, 1992). The shared educational background of those circulating among these different networks is also a foundational aspect of socialization processes that produces conformity in outlook and common styles of thinking (Saint-Martin, 2004).

In an article on the training of accountants, Hines talks about the "dominant positivist worldview" in the account profession, where it "is assumed that economic reality exists independently of accounting practices and that the major role of accounting is to communicate that reality" (1989, p. 53). As Pollitt and Summa found in their interviews and analysis of the reports published by five SAIs, many auditors see performance auditing as a "science" and see their work as founded on the "positivist myth that there is only one true story to be told" (1996, p. 44). They see their role as producing information that is "authoritative, unbiased, above mere political argument, objective, conclusive" (Pollitt \& Summa, 1996, p. 44). But as discussed earlier, the shift from old-fashioned financial audit to performance auditing has made such expectations increasingly difficult 
to meet. The traditional audit criteria of procedural correctness have been supplemented by more complex and slippery criteria of economy, efficiency and effectiveness (Radford, 1991). Whereas in traditional financial auditing, accounts are certified as constituting a "true and fair account", it is more difficult to make a comparable epistemological claim with regard to performance auditing.

VFM audit, because of its similarities with policy analysis and evaluation, also challenges the independence of SAIs. One of the goals of performance auditing is to help government improve the "three Es" of its management practices. But when SAIs begin to make usefulness to audited bodies a major criterion of their work this can conflict with their original mission of fearlessly reporting waste, inefficiency and ineffectiveness in public administration. If SAIs start to play the "quasi-consultancy role of helping audited bodies to improve their performances then it would be easy for cosy, less-than independent relationships to develop" (Pollitt \& Summa, 1997, p. 324).

The independence of SAIs is based on two things: the law that created them and their knowledge base. Auditors are part of an authoritative system of controls in the set of public bodies that constitute a democratic government, and their work is based on statutory powers and a mandate which more or les defines the limits of their territory. The law requires them to approach their work form the perspective of guardianship and control, with a basic role of holding public bodies to account for the expenditures of public funds. Regarding their knowledge base, traditional financial auditing, with its focus on numbers, used to strengthen SAIs' sense of independence (Vollmer, 2003). It 
provided methods and concepts that allow state auditors to produce information that was seen as objective and credible. But the arrival of VFM audit generated uncertainties by making that "positivist myth" more difficult to sustain. The synoptic model provided symbolic reassurance that the values of independence and objectivity were untouched by the auditors' new role in policy evaluation. It provided a "rational fiction" (McNamara, 2002) for securing legitimacy in public life.

\section{Conclusion}

In 1959, Lindblom showed that theories describing decision-making as a rational, apolitical and technical process were based on contestable arguments and inconclusive empirical evidence. But 50 years later such rationalist theories still form the primary theoretical lenses through which independent bureaucracies like SAIs analyse the performance of government entities. To understand why such organizations embrace the synoptic model despite its empirical weaknesses, this article has focused on its symbolic functions in legitimating the role of SAIs in performance auditing and in conveying credibility to external audiences in the broader political and social environment.

Our analysis reveals that while independent bureaucracies might be more likely to adopt rationalist politics as a strategy for legitimising their activities, it is the combination of several factors that explains why SAI's are particularly prone to embrace the synoptic model. In contrast to other independent bureaucracies, the SAI is not part of a larger network of societal stakeholders that it coordinates and from whose input it derives legitimacy. Institutionally speaking SAIs are conceived to be "above politics". 
Furthermore, while evaluation practice is multidisciplinary and there is no "profession" in the strict sense, auditing constitutes a profession with clear rules and standards of practice. As such auditing is characterized by a culture emphasising specific values, namely the fact-value dichotomy and the objectivation of social reality through quantitative methods. And finally, the rise of new public management created new opportunities for SAI's to expand their realm of influence.

But, one might argue, is not all politics prone to sell its policy choices as the result of rational analysis? While governments tend to sell their policies as the "right" choice taking into account the current state of knowledge, this does not constitute their primary source of legitimacy. They have been elected because of the values they represent, and this allows them to more openly acknowledge the value-laden character of their choices.

As our analysis demonstrates, Lindblom's work on incrementalism as mode of analysis and politics remains a valuable tool for thinking about today's issues in public policy and public administration. Other contributions in this special issue argue that some of his assumptions might not hold up anymore or have been absorbed or eclipsed by other, newer theories. Nevertheless, key ideas underpinning incrementalism, namely that there is no fact-value dichotomy and that policy-making does not consist of matching means to ends, have been reinforced by theoretical developments since the 1980s (argumentative turn in policy analysis, new institutionalism, theories on problem definition and agenda setting) and still constitute valuable insights for policy analysis. More than half a century after Lindblom's seminal article was published, this is sure enough of a reason to 
celebrate the impact his ideas had on the development of public policy and public administration as a discipline. 


\section{$\underline{\text { References }}$}

Amy, D. J. (1984). Toward a Post-Positivist Policy Analysis. Policy Studies Journal, 13 (1), 207-211.

Barzelay, M. (1997). Central Audit Institutions and Performance Auditing. Governance, 10 (3), 235-260

Behn, R. D. (2001). Rethinking Democratic Accountability. Washington, D.C.: Brookings Institution Press.

Borras, S., Koutakalis, Ch. \& Wendler, F. (2007). European Agencies and Input Legitimacy. Journal of European Integration, 29 (5), 583-600.

Boswell, Ch. (2009). The Political Uses of Expert Knowledge: Immigration Policy and Social Research. Cambridge: Cambridge University Press.

Boswell, Ch. (2008). The Political Functions of Expert Knowledge: Knowledge and Legitimation in European Union Immigration Policy. Journal of European Public Policy, 15 (4), 471-488.

Bowerman, M., Humphrey, Ch. \& Owen, D. (2003). Struggling for Supremacy: The Case of UK Public Audit Institutions. Critical Perspectives on Accounting, 14, 1-22.

Bowles, P. \& White, G. (1994). Central Bank Independence: A Political Economy Approach. Journal of Development Studies, 31 (2), 235-264.

Carpenter, D. P. (2001). The Forging of Bureaucratic Autonomy. Princeton, New Jersey: Princeton University Press.

Carpenter, D. P. (2010). Reputation and Power: Organizational Image and Pharmaceutical Regulation at the FDA. Princeton, New Jersey: Princeton University Press.

Chelimsky, E. (1985). Comparing and Contrasting Auditing and Evaluation: Some Notes on Their Relationship. Evaluation Review, 9 (4), 483-503.

Clarke, J. (2005). Producing Transparency? Evaluation and the Governance of Public Services. In In G. Drewry, C. Greeve \& T. Tanquerel, Contracts, Performance Measurement and Accountability in the Public Sector (pp.41-58). Amsterdam: IOS Press.

Corner, D. \& Drewry, G. (2005). The Implications of Public Service Reform for Accountability and Audit. In G. Drewry, C. Greeve \& T. Tanquerel, Contracts, Performance Measurement and Accountability in the Public Sector (pp.59-78). Amsterdam: IOS Press. 
Dehousse, R. (1997). Regulation by Networks in the European Community: The Role of European Agencies. Journal of European Public Policy, 4 (2), 246-61.

DeLeon, Peter (1997). Democracy and the Policy Sciences. Albany: State University of New York Press.

DiMaggio, P. J. \& Powell, W. W. (1983). The Iron Cage Revisited: Institutional Isomorphism and Collective Rationality in Organizational Fields. American Sociological Review, 48 (2), pp.147-160.

Dror, Y. (1964). Muddling Through: 'Science' or Inertia? Public Administration Review, 24, pp.153-57.

Eberlein, B. \& Grande, E. (2005). Beyond Delegation: Transnational Regulatory Regimes and the EU Regulatory State. Journal of European Public Policy, 12 (1), 89-112

Ferris, T. (2010). The Science of Liberty: Democracy, Reason and the Laws of Nature. New York: Harper.

Fischer, F. (2009). Democracy \& Expertise: Reorienting Policy Inquiry. Oxford: Oxford University Press.

Fischer, F. (2003). Reframing Public Policy: Discursive Politics and Deliberative Practices. Oxford: Oxford University Press.

Gabler, Melissa (2010). Norms, Institutions and Social Learning. Global Environmental Politics, 10 (2), pp.80-117.

Garson, D. G. (1981). From Policy Science to Policy Analysis: A Quarter Century of Progress? Policy Studies Journal, 9 (4), pp. 535-544.

Gilardi, F. (2008). Delegation in the Regulatory State. Edward Elgar.

Glynn, J. J. (1985). Value for Money Auditing: An International Review and Comparison. Financial Accountability \& Management, 1 (2), 113-128.

Good, D. (2007). The Politics of Public Money: Spenders, Guardians, Priority Setters and Financial Watchdogs. Toronto: Toronto University Press.

Guba, E. G., \& Lincoln, Y. S. (1989). Fourth generation evaluation. Newbury Park: Sage.

Haas, P. M. (1992). Introduction: Epistemic Communities and International Policy Coordination. International Organization, 46 (1), pp.1-35. 
Hawkesworth, M. E. (1988). Theoretical Issues in Policy Analysis. Albany: State University of New York Press.

Henkel, M. (1991). The New Evaluative State. Public Administration, 69 (Spring), 121136.

Henkel, M. (1991a). Government, Evaluation and Change. London: Jessica Kingsley Publishers.

Hines, R. D. (1989). The Sociopolitical Paradigm in Financial Accounting Research. Accounting, Auditing \& Accountability Journal, 2 (1), pp. 52-76.

Humphrey, J. C. (2001). Bewitched or Bewildered? Facts and Values in Audit Commission Texts. Local Government Studies, 2 (summer), 19-43.

Humphrey, J. C. (2002). A Scientific Approach to Politics? On the Trail of the Audit Commission. Critical Perspectives on Accounting, 13, 39-62.

Levy, R. (1996). Managing Value-for-Money Audit in the European Union: The Challenge of Diversity. JCMS: Journal of Common Market Studies, 34 (4), 509-529.

Lindblom, Ch. (1959). The Science of Muddling Through. Public Administration Review, 19 (2), 79-88.

Lindblom, Ch. (1979). Still Muddling, Not Yet Through. Public Administration Review, 39 (6), 517-526.

Lindblom, Ch. (1992). Inquiry and Change: The Troubled Attempt to Shape Society. New Haven: Yale University Press.

Leeuw, F. L. (1996). Auditing and evaluation: Bridging a gap, worlds to meet? New Directions for Evaluation, 1996 (71), 51-60.

Majone, G. (1989). Evidence, Argument and Persuasion in the Policy Process. New Haven: Yale University Press.

Majone, G. (1999). The Regulatory State and its Legitimacy Problems. West European Politics, 22 (1), 1-24.

Malloy, J. (2003). Between Colliding Worlds: The Ambiguous Existence of Government Agencies for Aboriginal and Women's Issues. Toronto: University of Toronto Press.

McNamara, K. (2002). Rational Fictions: Central Bank Independence and the Social Logic of Delegation. West European Politics, 25 (1), pp.47-76. 
McSwite, O.C. (1997). Legitimacy in Public Administration. Thousand Oaks, Cal: Sage Publications.

McSweeney, B. (1988). Accounting for the Audit Commission. Political Quarterly, 59, $28-43$.

Meyer, J. W. \& Scott, W. R. (1983). Organizational Environments: Ritual and Rationality. London: Sage.

Miller, P. (2001). Governing By Numbers: Why Calculative Practices Matter. Social Research, 68 (2), 379-396.

Nagel, S. S. (2001). Handbook of Public Policy Evaluation. Sage Publications.

Pal, L. A. (1992). Public Policy Analysis. $2^{\text {nd }}$ edition. Scarborough: Nelson Canada.

Pal, L. A. (1993). Interests of State: the Politics of Language, Multiculturalism and Feminism in Canada. Montreal-Kingston: McGill-Queen's University Press.

Pawson, R., \& Tilley, N. (1997). Realistic Evaluation. London: Sage.

Pollitt, Ch. (2003). Performance Audit in Western Europe: Trends and Choices. Critical Perspectives on Accounting, 14 (1-2), 157-170.

Pollitt, Ch. \& Summa, H. (1996). Performance Audit and Evaluation: Similar Tools, Different Relationships? New Directions for Evaluation, 71, 29-50.

Pollitt, Ch. \& Summa, H. (1997). Reflexive Watchdogs? How Supreme Audit Institutions Account for Themselves. Public Administration, 75 (Summer), 313-336.

Pollitt, Ch. \& Summa, H. (1999). Performance or Compliance? Performance Audit and Public Management in Five Countries. Oxford: Oxford University Press.

Porter, Th. M. (1995). Trust in Numbers: The Pursuit of Objectivity in Science and Public Life. Princeton, New Jersey: Princeton University Press.

Power, M. (1997). The Audit Society: Rituals of Verification. London: Oxford University Press.

Power, M. (2003). Evaluating the Audit Explosion. Law and Policy, 25 (3), 185-202.

Radaelli, C. M. (2000). Policy Transfer in the European Union: Institutional Isomorphism as a Source of Legitimacy. Governance, 13 (1), pp.25-43.

Radford, M. (1991). Auditing for Change: Local Government and the Audit Commission. The Modern Law Review 54 (6), 912-932. 
Roberts, A. (1996). Worrying About Misconduct: the Control Lobby and the PS 2000 Reforms. Canadian Public Administration, 39 (4), pp.489-523.

Rosenbloom, D. H. (2008). The Politics-Administration Dichotomy in US Historical Context. Public Administration Review, 68 (1), pp.57-60.

Rossi, P. H., Lipsey, M. W., \& Freeman, H. E. (2004). Evaluation: A Systematic Approach (7th ed.). Thousand Oaks: Sage.

Saint-Martin, D. (2004). Managerialist Advocate or "Control Freak"? The Janus-faced Office of the Auditor General. Canadian Public Administration, 47 (2), pp.121-140.

Sharpf, F. (1999). Governing in Europe: Effective and Democratic? New York: Oxford University Press.

Schrefler, L. (2010). The Usage of Scientific Knowledge by Independent Regulatory Agencies. Governance, 23 (2), 309-330.

Stone, Deborah (2002). Policy Paradox: The Art of Political Decision Making. $3^{\text {rd }}$ ed. New York: W. W. Norton \& Co.

Sutherland, S. L. (1986). The Politics of Audit. Canadian Public Administration, 29 (1), pp.118-148.

Thatcher, M. (2002). Delegation to Independent Regulatory Agencies. West European politics, 25 (1), pp. 125-147.

Vibert, F. (2007). The Rise of the Unelected: Democracy and the New Separation of Powers. New York: Cambridge University Press.

Vollmer, H. (2003). Bookkeeping, Accounting, Calculative Practice. Critical Perspectives on Accounting, 3, 353-381.

Weiss, C. H. (1998). Evaluation (2nd ed.). Upper Saddle River: Prentice Hall.

Wisler, C. (1996). Editor's notes. New Directions for Evaluation, 1996 (71), 1-5.

Yates, D. (1982). Bureaucratic Democracy. Cambridge, Ma: Harvard University Press. 